\title{
Puna-apilasäilörehun ruokinnallinen arvo lypsylehmän ainoana karkearehuna ja seoksena heinäkasvisäilörehun kanssa
}

\author{
Pirjo Pursiainen ${ }^{1}$, Seija Jaakkola ${ }^{1}$, Mikko Tuori ${ }^{2}$ ja Aila Vanhatalo ${ }^{1}$ \\ ${ }^{1)}$ Kotieläintieteen laitos, PL 28, 00014 Helsingin yliopisto, etunimi.sukunimi@helsinki.fi \\ ${ }^{2)}$ MTT, Kotieläintuotannon tutkimus, Tervamäentie 179, 05840 Hyvinkää, etunimi.sukunimi@mtt.fi
}

\section{Tiivistelmä}

Tutkimuksessa selvitettiin puna-apilasta (A1) ja heinäkasveista (N2) tehtyjen säilörehujen vaikutusta lypsylehmien rehun syöntiin, rehuannoksen sulavuuteen, maidontuotantoon ja maidon koostumukseen. Rehut korjattiin samanaikaisesti ja niitä syötettiin joko ainoana karkearehuna tai seoksena (A1N2, 1:1 kuiva-aineessa). Kontrollina oli samasta heinäkasvinurmesta neljä päivää aikaisemmin tehty säilörehu (N1). Kasvustot niitettiin niittomurskaimella, esikuivattiin ja paalattiin pyöröpaaleihin muurahaishappopohjaista säilöntäainetta käyttäen.

Tutkimus tehtiin tasapainotetun $4 \times 4$ latinalaisen neliön mukaisesti. Kokeessa oli kahdeksan ay-lehmää, jotka jaettiin tuotoksen mukaan kahteen blokkiin (2-3 kertaa poikineet ja ensikot). Lehmät saivat säilörehua vapaasti. Väkirehu oli ohran ja kauran (1:1) sekä rypsipuristeen (238 g/kg väkirehua) seos, jota annettiin 10,5 (blokki 1) tai $8,4 \mathrm{~kg} / \mathrm{pv}$ (blokki 2). Lisäksi lehmät saivat kivennäisrehua ja ruokasuolaa.

Säilörehujen kuiva-ainepitoisuudet olivat 261 (N1), 337 (A1) ja 372 (N2) g/kg. Apilasäilörehu ja samaan aikaan niitetty heinäkasvisäilörehu olivat rajoittuneesti käyneitä ja sisälsivät runsaasti sokeria. Lisäksi ammoniumtypen osuus kokonaistypestä oli pieni. Aikaisemmin korjattu heinäkasvisäilörehu oli hieman pidemmälle käynyttä. Se sisälsi myös runsaasti etanolia ja ammoniumtypen osuus kokonaistypestä oli melko suuri $(81 \mathrm{~g} / \mathrm{kg})$. Säilörehujen orgaanisen aineen (OA) in vitro -sulavuudet olivat oli 718 (N1), 711 (A1) ja 670 (N2) g/kg OA ja D-arvot vastaavasti $664,640 \mathrm{ja} 623 \mathrm{~g} / \mathrm{kg} \mathrm{KA}$.

Lehmät söivät puhdasta apilasäilörehua $1,3 \quad \mathrm{~kg} \quad \mathrm{KA} / \mathrm{pv}$ enemmän $(\mathrm{P}<0,01)$ kuin samanaikaisesti niitettyä heinäkasvisäilörehua. Näiden rehujen seosta lehmät söivät lähes yhtä paljon kuin puhdasta apilasäilörehua (11,2 (N1), 12,0 (A1), 10,7 (N2) ja 11,8 (A1N2) kg KA/pv). Apilarehua syötettäessä lehmät saivat enemmän raakavalkuaista, ohutsuolesta imeytyvää valkuaista $(\mathrm{P}<0,001) \mathrm{ja}$ rehuyksikköjä $(\mathrm{P}<0,01)$ sekä vähemmän NDF-kuitua $(\mathrm{P}<0,001)$ kuin samanaikaisesti niitettyä heinäkasvirehua syötettäessä. A1-ruokinnan orgaanisen aineen ja raakavalkuaisen sulavuudet olivat hieman suuremmat $(\mathrm{P}<0,10)$ kuin N2-ruokinnan. Seoksena syötettäessä apila- ja heinäkasvirehuilla oli yhdysvaikutusta vain rehuannoksen raakavalkuaisen sulavuudessa, sillä A1N2-ruokinnan sulavuus oli pienempi kuin A1- ja N2-ruokintojen keskimäärin $(\mathrm{P}<0,10)$. Rehuannoksen kuidun sulavuus oli apilarehulla ruokittaessa numeerisesti pienempi kuin muissa ruokinnoissa. Myös myöhempi rehunkorjuu heikensi $(\mathrm{P}<0,05)$ kuidun sulavuutta, vaikka ero heinäkasvirehujen korjuuajassa oli vain neljä päivää.

Apilarehua syöneet lehmät lypsivät keskimäärin $1,5 \mathrm{~kg} / \mathrm{pv}$ enemmän $(\mathrm{P}<0,05)$ kuin samanaikaisesti tehtyä heinäkasvisäilörehua syöneet lehmät. Kasvilajeilla ei kuitenkaan ollut yhdysvaikutusta maidontuotannossa, sillä seoksella ruokittujen lehmien maitotuotos oli $0,9 \mathrm{~kg} / \mathrm{pv}$ pienempi kuin puhdasta apilarehua syöneiden lehmien tuotos. Koska apilarehu hieman pienensi maidon rasvapitoisuutta $(\mathrm{P}<0,10)$ verrattuna $\mathrm{N} 2$-rehuun, ei energiakorjatussa maitotuotoksessa $[29,2$ (N1), 30,0 (A1), 29,1 (N2) ja 29,6 (A1N2)] ollut eroa. Ruokinta ei vaikuttanut maidon valkuaispitoisuuteen, mutta runsaamman maitotuotoksen vuoksi apilaa syöneiden lehmien valkuaistuotos oli suurempi $(\mathrm{P}<0,05)$ kuin samanaikaisesti niitettyä heinäkasvirehua syöneiden lehmien valkuaistuotos. Apila lisäsi $(\mathrm{P}<0,01)$ maidon laktoosipitoisuutta verrattuna N2-rehuun. Apila lisäsi maidon ureapitoisuutta ja heikensi jonkin verran rehuvalkuaisen hyväksikäyttöä maidontuotantoon samanaikaisesti niitettyyn heinäkasvirehuun verrattuna $(\mathrm{P}<0,001)$.

Asiasanat: lypsylehmä, puna-apilasäilörehu, heinäkasvisäilörehu, maidontuotanto 


\section{Johdanto}

Puna-apilapitoinen säilörehu on yleensä lisännyt säilörehun syöntiä ja maitotuotosta puhtaaseen heinäkasvisäilörehuun verrattuna. Vanhatalon ja Jaakkolan (2006b) kirjallisuuskatsauksen mukaan säilörehun kuiva-aineen syönti ja energiakorjattu maitotuotos lisääntyivät keskimäärin 1,3 ja $0,9 \mathrm{~kg}$ päivässä puna-apilan osuuden säilörehussa vaihdellessa välillä $30-70 \%$. Sen sijaan puhdasta punaapilasäilörehua syötettäessä vaikutukset syöntiin olivat hyvin vaihtelevia. Joissakin kokeissa lehmät söivät puhdasta puna-apilasäilörehua huomattavasti enemmän kuin vertailtavaa heinäkasvisäilörehua, mutta toisissa kokeissa taas selvästi vähemmän. Myös Huhtasen ym. (2007) data-analyysin mukaan nurmipalkokasvien, kuten puna-apilan, vaikutus syöntiin on vaikeammin ennustettavissa silloin kun sen osuus säilörehusta ylittää $50 \%$. Säilörehun syöntiin vaikuttavat säilörehun raaka-aineena käytetyn kasvilajin ja kasvuston kehitysasteen lisäksi myös monet muut tekijät kuten säilörehun kuivaainepitoisuus ja säilönnällinen laatu. Kasvilajien välistä vertailua vaikeuttaa usein se, että näissä tekijöissä esiintyy paljon rehujen välistä vaihtelua paitsi eri tutkimusten välillä myös saman tutkimuksen sisällä. Esimerkiksi Pursiaisen ym. (2006) tutkimuksessa apilasäilörehut olivat pidemmälle käyneitä kuin vertailurehuina olleet heinäkasvisäilörehut.

Tässä tutkimuksessa selvitettiin puna-apila- ja heinäkasvisäilörehujen vaikutusta lypsylehmien rehun syöntiin, rehuannoksen sulavuuteen, maidontuotantoon ja maidon koostumukseen. Samana päivänä niitettyjä apila- ja heinäkasvisäilörehuja syötettiin sekä ainoana karkearehuna että seoksena. Tavoitteena oli tutkia onko kasvilajien seoksella saavutettavissa edullista yhdysvaikutusta ruokinnassa. Kontrollirehuna oli heinäkasvisäilörehu, joka oli korjattu edellä mainittuja rehuja aikaisemmalla kasvuasteella ja jonka orgaanisen aineen sulavuus oli lähes sama kuin apilarehun. Tutkimus tehtiin MMM:n Luomututkimusohjelman projektissa 'Puna-apila tehokkaasti luomumaidoksi'.

\section{Aineisto ja menetelmät}

Tutkimus tehtiin Viikin opetus- ja tutkimustilan navetassa talvella 2006. Koerehuina olivat punaapilan (lajike Varte, kukinta alussa) ensikasvusta (A1) ja heinäkasvinurmen (timotei, nurminata, monivuotinen raiheinä) ensikasvusta (N2) samana päivänä niitetyt rehut, joita syötettiin sekä ainoana karkearehuna että seoksena (A1N2, 1:1 kuiva-aineessa). Apilaa ei lannoitettu. Kontrollirehuna oli samasta heinäkasvinurmesta aikaisemmalla kasvuasteella tehty säilörehu (N1). Kasvustot niitettiin niittomurskaimella, esikuivattiin ja paalattiin pyöröpaaleihin muurahaishappopohjaista säilöntäainetta (AIV 2 Plus 5 1/t, Kemira GrowHow) käyttäen.

Tutkimus tehtiin tasapainotetun $4 \times 4$ latinalaisen neliön mukaisesti. Kunkin jakson 12 ensimmäistä päivää olivat valmistuskautta ja koepäivät 13-19 keruukautta. Kokeessa oli kahdeksan ay-lehmää, jotka jaettiin tuotoksen mukaan kahteen blokkiin (2-3 kertaa poikineet, ensikot). Tutkimuksen alkaessa blokin 1 lehmien maitotuotos oli keskimäärin 38,2 (s.d. 1,8) kg päivässä ja blokin 2 lehmien 29,1 (s.d. 1,2) kg päivässä. Blokin 1 lehmien poikimisesta oli kulunut 49-94 päivää ja blokin 2 lehmien poikimisesta 38-102 päivää.

Lehmät saivat säilörehua vapaasti. Säilörehua jaettiin kolme kertaa päivässä. Säilörehuista määritettiin kuiva-ainepitoisuus paaleittain ja rehujen A1 ja N2 kuiva-ainepitoisuuksien perusteella laskettiin niiden määrät seoksessa A1N2. Seos tehtiin käsin ruokinnan yhteydessä. Väkirehuna oli ohran ja kauran (1:1) sekä rypsipuristeen (23.8 \% väkirehun määrästä) seos, jota annettiin 10,5 (blokki 1) tai $8,4 \mathrm{~kg} / \mathrm{pv}$ (blokki 2). Koska apilassa on runsaasti kalsiumia, täydennettiin apilasäilörehua syöneiden lehmien väkirehuannosta niukasti kalsiumia sisältävällä kivennäisrehulla (Tarmo, Melica Finland; $\mathrm{Ca} \mathrm{3,} \mathrm{P} \mathrm{5,} \mathrm{Mg} \mathrm{65,} \mathrm{Na} 65 \mathrm{~g} / \mathrm{kg}$ ). Myös heinäkasvisäilörehuja syöneet lehmät saivat kivennäislisän (Onni, Melica Finland; Ca 205, P 27, Mg 85, Na 72 g/kg) ja ruokintakalkkia. Lisäksi kaikki lehmät saivat ruokasuolaa 100 g/pv. Väkirehu jaettiin kuudessa yhtä suuressa erässä. Rehut ja jäännösrehut punnittiin päivittäin.

Maitotuotos mitattiin jokaisella lypsykerralla (Tru-Test WB). Jokaisen jakson lopussa maidosta otettiin näyte neljältä peräkkäiseltä lypsykerralta. Yhdistetystä näytteestä määritettiin Valion Seinäjoen aluelaboratoriossa rasva-, valkuais-, laktoosi- ja ureapitoisuus infrapuna-analysaattorilla. Lisäksi otettiin näyte rasvahappojen määrittämistä varten. Eläimet punnittiin ennen kokeen alkua ja jokaisen jakson lopussa kahtena peräkkäisenä päivänä.

Keruukauden aikana säilö- ja väkirehuista kerättiin päivittäin näytettä rehunpunnitusten yhteydessä analyysejä varten. Rehuannoksen sulavuuden määrittämiseksi 1. blokin lehmiltä kerättiin jokaisen jakson lopussa sontanäyte viitenä peräkkäisenä päivänä kaksi kertaa päivässä. Sulavuus 
määritettiin käyttäen merkkiaineena happoon liukenematonta tuhkaa (AIA). Lisäksi säilörehujen orgaanisen aineen sulavuus in vitro määritettiin pepsiinisellulaasiliukoisuus-menetelmällä.

Jokaisen jakson viimeisenä päivänä lehmiltä otettiin verinäyte häntäsuoneen asetetetusta kanyylista klo 5 (ennen ruokintaa) ja klo 8. Häntäsuoni kanyloitiin näytteenottoa edeltävänä iltana. Näytteenottoaikojen yli yhdistetyistä plasmoista määritettiin glukoosi, insuliini, vapaat rasvahapot (NEFA), etikkahappo ja $\beta$-hydroksivoihappo (BHBA).

Syönti- ja tuotostiedot laskettiin jokaiselta jaksolta koepäivien 13-19 keskiarvotiedoista. Rehuarvoja laskettaessa väkirehulle käytettiin rehutaulukoiden sulavuuskertoimia ja säilörehulle in vitro D-arvoa (MTT 2006). Tulokset testattiin SASin Mixed proseduurilla. Tilastollisessa mallissa oli mukana ruokinta, blokki, jakso sekä blokin ja jakson yhdysvaikutus. Eläin oli blokin sisällä satunnaistekijänä. Ruokinnan vaikutusta tutkittiin edelleen jakamalla se ortogonaalisiin kontrasteihin; A1 vs. N2, yhdysvaikutus $\mathrm{A} 1+\mathrm{N} 2 \times \mathrm{A} 1 \mathrm{~N} 2$ ja kasvuaika (N1 vs. A1+ N2+A1N2).

\section{Tulokset ja tulosten tarkastelu}

\section{Rehujen koostumus}

Apila saatiin esikuivattua aurinkoisessa säässä hyvin (kuiva-ainepitoisuus noin $300 \mathrm{~g} / \mathrm{kg}$ ), mikä näkyi apilasäilörehun hyvänä säilöntälaatuna (taulukko 1). Apilasäilörehu sekä samaan aikaan niitetty heinäkasvisäilörehu olivat rajoittuneesti käyneitä ja niissä oli runsaasti sokeria. Liukoisen typen osuus rehun kokonaistypestä oli apilarehussa tyypillisesti pienempi kuin heinäkasvirehuissa (Vanhatalo ja Jaakkola 2006b). Aikaisemmin korjattu heinäkasvisäilörehu oli pidemmälle käynyttä ja sisälsi

Taulukko 1. Säilörehujen raaka-aineiden kemiallinen koostumus sekä rehujen koostumus, säilönnällinen laatu ja rehuarvot.

\begin{tabular}{|c|c|c|c|c|c|c|c|}
\hline & \multicolumn{3}{|c|}{ Raaka-aine } & \multicolumn{3}{|c|}{ Säilörehu } & \multirow[b]{2}{*}{$\begin{array}{l}\text { Väki- } \\
\text { rehu }\end{array}$} \\
\hline & N1 & $\mathbf{A 1}$ & $\mathbf{N 2}$ & N1 & $\mathbf{A 1}$ & $\mathbf{N 2}$ & \\
\hline Niittopäivä & 16.6 . & 20.6 . & 20.6 . & & & & \\
\hline Paalauspäivä & 17.6. & 22.6. & 21.6. & & & & \\
\hline Kuiva-aine, $\mathrm{g} / \mathrm{kg}^{\mathrm{a}}$ & 242 & 307 & 349 & 261 & 337 & 372 & 873 \\
\hline $\mathrm{pH}$ & & & & 4,20 & 4,39 & 4,38 & \\
\hline \multicolumn{8}{|l|}{ Koostumus, g/kg KA } \\
\hline Tuhka & 76 & 101 & 71 & 75 & 100 & 69 & 69 \\
\hline Orgaaninen aine & 924 & 899 & 929 & 925 & 900 & 931 & 931 \\
\hline Raakavalkuainen & 115 & 175 & 103 & 123 & 177 & 108 & 177 \\
\hline NDF-kuitu & 585 & 372 & 612 & 507 & 335 & 563 & 237 \\
\hline iNDF & & & & 75 & 76 & 85 & \\
\hline Maitohappo & & & & 68 & 57 & 34 & \\
\hline Etikkahappo & & & & 13 & 14 & 9 & \\
\hline Propionihappo & & & & 0,06 & 0,01 & 0,04 & \\
\hline Voihappo & & & & 0,53 & 0,19 & 0,16 & \\
\hline VFA yhteensä & & & & 81 & 72 & 43 & \\
\hline Vesiliukoiset hiilihydraatit & 120 & 102 & 111 & 57 & 98 & 117 & \\
\hline Etanoli & & & & 75 & 17 & 35 & \\
\hline Liukoinen $\mathrm{N}, \mathrm{g} / \mathrm{kg} \mathrm{N}$ & & & & 727 & 495 & 691 & \\
\hline Ammonium-N, g/kg N & & & & 81 & 42 & 51 & \\
\hline $\mathrm{OAS}^{\mathrm{b}}$ in vitro & & & & 718 & 711 & 670 & \\
\hline$D-\operatorname{arvo}^{c}$ & $670^{\mathrm{d}}$ & 660 & 630 & 664 & 640 & 623 & \\
\hline OIV & & & & 81 & 86 & 76 & 110 \\
\hline PVT & & & & -14 & 29 & -21 & 1 \\
\hline $\mathrm{ME}, \mathrm{MJ} / \mathrm{kg} \mathrm{KA}$ & & & & 10,63 & 10,25 & 9,97 & 12,33 \\
\hline $\mathrm{RY} / \mathrm{kg} \mathrm{KA}$ & & & & 0,91 & 0,88 & 0,85 & 1,054 \\
\hline Syönti-indeksi ${ }^{\mathrm{e}}$ & & & & 94 & 94 & 92 & \\
\hline Syönti-indeksi ${ }^{\mathrm{f}}$ & & & & 99 & 120 & 101 & \\
\hline
\end{tabular}

${ }^{a}$ Säilörehujen kuiva-ainepitoisuus korjattu Huidan ym. (1986) mukaan; ${ }^{b}$ pepsiinisellulaasiliukoisuus, g/kg OM; ' Sulavan orgaanisen aineen pitoisuus, g/kg KA (raaka-aineet Valion NIR-määritys ja säilörehut OAS-sulavuus); ${ }^{\mathrm{d}}$ Näyte otettu kasvustosta 14.6.; ${ }^{\mathrm{e}}$ Huhtanen ym. (2002); ${ }^{\mathrm{f}}$ Huhtanen ym. (2007). 
runsaasti etanolia. Lisäksi ammoniumtypen osuus kokonaistypestä oli melko suuri. Voihapon määrä oli vähäinen kaikissa rehuissa.

Kemialliselta koostumukseltaan apilasäilörehu erosi heinäkasvisäilörehuista lähinnä suuremman tuhka- ja valkuaispitoisuuden ja pienemmän NDF-pitoisuuden vuoksi (taulukko 1). Sen sijaan sulamatonta kuitua (iNDF) aikaisemmin korjattu heinäkasvisäilörehu ja apilasäilörehu sisälsivät saman verran. Myös orgaanisen aineen in vitro sulavuus oli näillä rehuissa lähes sama.

\section{Rehun syönti ja rehuannoksen sulavuus}

Lehmät söivät $1,3 \mathrm{~kg} \mathrm{KA} / \mathrm{pv}$ enemmän puhdasta puna-apilasäilörehua kuin samaan aikaan niitettyä heinäkasvisäilörehua $(\mathrm{P}<0,01)$ (taulukko 2). Kun näitä rehuja syötettiin seoksena, söivät lehmät seosta lähes saman verran kuin puhdasta apilasäilörehua ja $0,6 \mathrm{~kg} \mathrm{KA} / \mathrm{pv}$ enemmän kuin aikaisemmin korjattua N1-rehua. Puhtaan apilarehun syönti oli lisäksi keskimäärin 0,8 kg KA/pv suurempi kuin aikaisemmin korjatun N1-rehun. Useissa muissakin tutkimuksissa lehmät ovat syöneet enemmän puna-apilasta (Dewhurst ym. 2003, Bertilsson ja Murphy 2003) tai puna-apilan ja heinäkasvien seoksesta (Heikkilä ym. 1992 ja 1996, Tuori ym. 2000 ja 2002, Kuoppala ym. 2006) tehtyä säilörehua kuin heinäkasvisäilörehua, mutta ei kuitenkaan kaikissa (Pursiainen ym. 2006). Nyt tehdyssä kokeessa lehmät söivät puhdasta apilarehua keskimäärin $1,3 \mathrm{~kg} \mathrm{KA} / \mathrm{pv}$ enemmän kuin aikaisemmassa kokeessa (Pursiainen ym. 2006) lähes samassa kehitysvaiheessa korjattua ensimmäisen sadon apilarehua. Apilarehun kuiva-ainepitoisuus oli nyt suurempi ja myös säilöntälaatu parempi kuin edellisessä kokeessa. Paremman säilöntälaadun vuoksi myöskään kasvuaika ei vaikuttanut lehmien säilörehun syöntiin, sillä lehmät söivät N1-rehua keskimäärin vain $0,5 \mathrm{~kg} \mathrm{KA} / \mathrm{pv}$ enemmän kuin N2rehua. Tosin säilörehujen korjuuajassa oli vain neljän päivän ero.

Lehmät saivat apilarehua syötettäessä hieman enemmän orgaanista ainetta kuin samaan aikaan niitettyä heinäkasvirehua syötettäessä $(\mathrm{P}<0,1)$ (taulukko 2). Apilarehuuokinnassa lehmät saivat myös enemmän raakavalkuaista, ohutsuolesta imeytyvää valkuaista $(P<0,001)$ ja rehuyksiköitä $(P<0,01)$ ja vähemmän kuitua $(\mathrm{P}<0,001)$ kuin samanaikaisesti niitettyä heinäkasvirehua syötettäessä. Eläinten ravintoaineiden saantiin kasvilajeilla ei ollut yhdysvaikutusta.

A1-ruokinnan orgaanisen aineen ja raakavalkuaisen sulavuudet olivat hieman suuremmat kuin N2-ruokinnan $(\mathrm{P}<0,1) \quad$ (taulukko 2). Seoksena syötettäessä apila- ja heinäkasvirehuilla oli yhdysvaikutusta, sillä seoksena ruokittaessa raakavalkuaisen sulavuus oli pienempi kuin apila- ja heinäkasvirehuruokintojen keskimäärin $(\mathrm{P}<0,10)$. Kuidun sulavuus oli apilasäilörehulla ruokittaessa numeerisesti pienempi kuin muissa ruokinnoissa. Myöhempi rehunkorjuu heikensi kuidun sulavuutta, vaikka eroa heinäkasvirehujen niittoajassa oli vain neljä päivää $(\mathrm{P}<0,05)$.

Taulukko 2. Lehmien rehun syönti, ravintoaineiden saanti ja rehuannoksen sulavuus.

\begin{tabular}{|c|c|c|c|c|c|c|c|c|}
\hline & \multirow[b]{2}{*}{$\begin{array}{c}\text { N1 } \\
(\mathrm{n}=8)\end{array}$} & \multirow[b]{2}{*}{$\begin{array}{c}\mathbf{A 1} \\
(\mathrm{n}=8)\end{array}$} & \multirow[b]{2}{*}{$\begin{array}{c}\mathbf{N} 2 \\
(\mathrm{n}=8)\end{array}$} & \multirow[b]{2}{*}{$\begin{array}{r}\mathbf{A 1 N 2} \\
(\mathrm{n}=8)\end{array}$} & \multirow[b]{2}{*}{ SEM } & \multicolumn{3}{|c|}{ Tilastollinen merkitsevyys } \\
\hline & & & & & & $\begin{array}{c}\text { A1 vs. } \\
\text { N2 }\end{array}$ & $\begin{array}{c}\text { Yhdys- } \\
\text { vaik. }\end{array}$ & $\begin{array}{c}\text { Kasvu- } \\
\text { aika }\end{array}$ \\
\hline \multicolumn{9}{|l|}{ Rehun syönti } \\
\hline Säilörehu, kg KA/pv & 11,2 & 12,0 & 10,7 & 11,8 & 0,60 & $* *$ & & \\
\hline Väkirehu, kg KA/pv & 8,5 & 8,3 & 8,5 & 8,3 & 0,16 & * & & \\
\hline Yhteensä, kg KA/pv & 19,6 & 20,3 & 19,2 & 20,1 & 0,50 & * & & \\
\hline Väkirehua, g/kg KA & 435 & 409 & 446 & 414 & 15,2 & $* *$ & & \\
\hline \multicolumn{9}{|l|}{ Ravintoaineiden saanti } \\
\hline Org. aine, $\mathrm{kg} / \mathrm{pv}$ & 18,1 & 18,6 & 17,8 & 18,6 & 0,46 & $\mathrm{o}$ & & \\
\hline Raakavalk., g/pv & 2859 & 3616 & 2644 & 3169 & 64,0 & $* * *$ & & $* * *$ \\
\hline Kuitu, g/pv & 7648 & 6007 & 8037 & 7245 & 263,4 & $* * *$ & & $*$ \\
\hline $\mathrm{ME}, \mathrm{MJ} / \mathrm{pv}$ & 223 & 226 & 211 & 222 & 5,0 & $* *$ & & \\
\hline $\mathrm{RY}, \mathrm{ry} / \mathrm{pv}$ & 19,0 & 19,3 & 18,0 & 19,0 & 0,43 & $* *$ & & \\
\hline $\mathrm{OIV}, \mathrm{g} / \mathrm{pv}$ & 1828 & 1955 & 1745 & 1873 & 37,8 & $* * *$ & & \\
\hline PVT, g/kg KA/pv & -8 & 18 & -11 & 3 & 0,8 & $* * *$ & & $* * *$ \\
\hline Sulavuus, g/kg & $(n=4)$ & $(n=4)$ & $(n=4)$ & $(n=4)$ & & & & \\
\hline Orgaaninen aine & 727 & 728 & 704 & 698 & 7,8 & $\mathrm{o}$ & & \\
\hline Raakavalkuainen & 697 & 704 & 679 & 669 & 9,7 & $\mathrm{o}$ & o & \\
\hline Kuitu & 593 & 518 & 562 & 522 & 16,2 & & & $*$ \\
\hline
\end{tabular}

Tilastollinen merkitsevyys $* * *=\mathrm{P}<0,001, * *=\mathrm{P}<0,01, *=\mathrm{P}<0,05, \mathrm{o}=\mathrm{P}<0,10$ 


\section{Maitotuotos ja maidon koostumus}

Apilarehua syöneet lehmät lypsivät keskimäärin $1,5 \mathrm{~kg} / \mathrm{pv}$ enemmän kuin samanaikaisesti niitettyä heinäkasvisäilörehua syöneet lehmät $(\mathrm{P}<0,05)$ (taulukko 3). Kasvilajien välillä ei kuitenkaan ollut merkitsevää yhdysvaikutusta maidontuotannossa. Apilan ja heinäkasvirehun seosta syöneiden lehmien maitotuotos oli keskimäärin $0,9 \mathrm{~kg} / \mathrm{pv}$ pienempi kuin puhdasta apilarehua syöneiden lehmien tuotos, vaikka rehun syönti oli lähes yhtä suuri. Energiakorjatussa maitotuotoksessa (EKM) ei ollut eroa, sillä apila pienensi hieman maidon rasvapitoisuutta verrattuna samaan aikaan niitettyyn heinäkasvirehuun $(\mathrm{P}<0,1)$ (taulukko 3). Maidon rasvapitoisuus on useissa aiemmissa tutkimuksissa ollut apilasäilörehulla ruokittaessa pienempi (Tuori ym. 2002, Bertilsson ja Murphy 2003, Vanhatalo ym. 2006c) tai yhtäsuuri (Vanhatalo ym. 2006a, Tuori ym. 2000) kuin heinäkasvisäilörehulla ruokittaessa. Pursiaisen ym. (2006) tutkimuksessa maidon rasvapitoisuus oli numeerisesti pienempi apilasäilörehulla kuin heinäkasvirehulla ruokittaessa lukuun ottamatta apilan ensikasvusta lähes tätä koetta vastaavassa kehitysvaiheessa tehtyä apilarehua. Ruokinta ei vaikuttanut maidon valkuaispitoisuuteen, mutta runsaamman maitotuotoksen vuoksi apilaa syöneiden lehmien valkuaistuotos oli suurempi kuin samaan aikaan niitettyä heinäkasvirehua syöneiden lehmien valkuaistuotos $(\mathrm{P}<0,05)$. Apilaruokinnan on todettu toisinaan pienentävän maidon valkuaispitoisuutta heinäkasviruokintoihin verrattuna (Vanhatalo ja Jaakkola 2006b). Kuten aikaisemmissa kokeissa (Pursiainen ym. 2006, Vanhatalo ym. 2006c) maidon laktoosipitoisuus ja -tuotos $(\mathrm{P}<0,01)$ olivat apilasäilörehulla ruokittaessa suuremmat kuin heinäkasvisäilörehulla ruokittaessa. Plasman glukoosin, vapaiden rasvahappojen, etikkahapon ja $\beta$-hydroksivoihapon pitoisuuksissa ei ollut eroja koekäsittelyiden välillä (tuloksia ei esitetty). Plasman insuliinipitoisuus oli kuitenkin suurempi $(\mathrm{P}<0,05)$ apila- kuin heinäkasvirehua syötetäessä $(6,4$ vs. $4,9 \mu \mathrm{U} / \mathrm{ml})$.

Apila lisäsi linolihapon, $\alpha$-linoleenihapon ja monityydyttämättämien rasvahappojen (PUFA) pitoisuutta maidossa $(\mathrm{P}<0,001)$, mutta vähensi kertatyydyttymättömien rasvahappojen (MUFA) pitoisuutta $(\mathrm{P}<0,05)$ verrattuna samanaikaisesti korjattuun heinäkasvirehuun (taulukko 3). Erityisesti $\alpha$-linoleenihapon pitoisuuden voimakas lisääntyminen maitorasvassa apilasäilörehua ruokittaessa

Taulukko 3. Maitotuotos, maidon koostumus ja rehun hyväksikäyttö

\begin{tabular}{|c|c|c|c|c|c|c|c|c|}
\hline & \multirow[b]{2}{*}{$\begin{array}{c}\mathbf{N 1} \\
(\mathrm{n}=8)\end{array}$} & \multirow[b]{2}{*}{$\begin{array}{c}\mathbf{A 1} \\
(\mathrm{n}=8)\end{array}$} & \multirow[b]{2}{*}{$\begin{array}{c}\mathbf{N} 2 \\
(\mathrm{n}=8)\end{array}$} & \multirow[b]{2}{*}{$\begin{array}{c}\text { A1N2 } \\
(\mathrm{n}=8)\end{array}$} & \multirow[b]{2}{*}{ SEM } & \multicolumn{3}{|c|}{ Tilastollinen merkitsevyys } \\
\hline & & & & & & $\begin{array}{c}\text { A1 vs. } \\
\text { N2 }\end{array}$ & $\begin{array}{c}\text { Yhdys- } \\
\text { vaik. }\end{array}$ & $\begin{array}{c}\text { Kasvu } \\
\text {-aika }\end{array}$ \\
\hline \multicolumn{9}{|l|}{ Maidontuotanto } \\
\hline Maito, kg/pv & 28,4 & 29,6 & 28,1 & 28,7 & 1,01 & $*$ & & \\
\hline $\mathrm{EKM}, \mathrm{kg} / \mathrm{pv}^{\mathrm{a}}$ & 29,2 & 30,0 & 29,1 & 29,6 & 0,89 & & & \\
\hline Rasva, g/pv & 1218 & 1228 & 1233 & 1244 & 47,0 & & & \\
\hline Valkuainen, g/pv & 944 & 984 & 931 & 949 & 21,1 & $*$ & & \\
\hline Laktoosi, g/pv & 1299 & 1370 & 1277 & 1315 & 44,6 & $* *$ & & \\
\hline \multicolumn{9}{|l|}{ Maidon koostumus } \\
\hline Rasva, g/kg & 43,0 & 41,5 & 43,7 & 43,3 & 1,36 & o & & \\
\hline Valkuainen, $\mathrm{g} / \mathrm{kg}$ & 33,4 & 33,3 & 33,2 & 33,3 & 0,78 & & & \\
\hline Laktoosi, g/kg & 45,8 & 46,3 & 45,5 & 45,8 & 0,64 & $* *$ & & \\
\hline Urea, $\mathrm{mg} / 100 \mathrm{ml}$ & 27 & 34 & 25 & 31 & 1,1 & $* * *$ & & $*$ \\
\hline \multicolumn{9}{|l|}{$\mathrm{g} / 100 \mathrm{~g}$ rasvahappoja } \\
\hline $\mathrm{C}_{18: 2}$ & 1,79 & 2,15 & 1,88 & 2,01 & 0,069 & $* * *$ & & $* * *$ \\
\hline $\mathrm{C}_{18: 3}$ & 0,42 & 0,82 & 0,42 & 0,62 & 0,021 & $* * *$ & & $* * *$ \\
\hline CLAcis-9,trans-11 & 0,49 & 0,55 & 0,52 & 0,57 & 0,034 & & $*$ & $* *$ \\
\hline PUFA & 2,69 & 3,52 & 2,82 & 3,20 & 0,105 & $* * *$ & & $* * *$ \\
\hline MUFA & 24,67 & 24,22 & 25,32 & 25,19 & 0,396 & $*$ & & \\
\hline Tyydyttymättömät & 27,36 & 27,74 & 28,13 & 28,39 & 0,467 & & & * \\
\hline Tyydyttyneet & 69,52 & 69,13 & 68,78 & 68,24 & 0,475 & & $\mathrm{o}$ & o \\
\hline Elop. muutos, $\mathrm{kg} / \mathrm{pv}$ & $-0,067$ & 0,282 & 0,368 & 0,045 & 0,1933 & & & \\
\hline Maidon N/rehun N & 32 & 27 & 35 & 29 & 0,6 & $* * *$ & o & $* *$ \\
\hline OIV:n hyv.käyttö ${ }^{\mathrm{b}}$ & 0,715 & 0,684 & 0,746 & 0,698 & 0,0155 & $* *$ & & \\
\hline OIV/EKM, g/kg ${ }^{\mathrm{c}}$ & 45,7 & 48,2 & 43,3 & 46,4 & 1,29 & $* *$ & & \\
\hline EKM kg/kg KA & 1,49 & 1,48 & 1,51 & 1,48 & 0,046 & & & \\
\hline
\end{tabular}

${ }^{a}$ Sjaunja ym. (1991); ${ }^{b}$ valkuaistuotos/(OIV:n saanti-OIV ylläpitoon); '(OIV:n saanti-OIV ylläpitoon)/EKM; Tilastollinen merkitsevyys $* * *=\mathrm{P}<0,001, * *=\mathrm{P}<0,01, *=\mathrm{P}<0,05, \mathrm{O}=\mathrm{P}<0,10$. 
heinäkasvirehuruokintaan verrattuna on havaittu aiemminkin (Dewhurst ym. 2003, Tuori ym. 2004, Vanhatalo ym. 2007). Tässä kokeessa $\alpha$-linoleenihapon osuus apilaruokinnassa oli kuitenkin selvästi pienempi kuin Vanhatalon ym. (2007) kokeessa aikaisin korjattua apilasäilörehua syötettäessä. Ero kokeiden välillä saattaa liittyä apilarehujen erilaiseen kuiva-ainepitoisuuteen, joka oli tässä kokeessa suurempi. Tämä viittaa mahdollisesti säilörehun raaka-aineen sisältämien rasvahappojen hapettumiseen jossain määrin esikuivauksen aikana. Myös kasvuasteessa on saattanut olla eroa rehujen välillä.

Rehuvalkuaisen hyväksikäyttö maidontuotannossa oli suhteellisen hyvä tässä kokeessa (taulukko 3). Apilarehu kuitenkin lisäsi jonkin verran maidon ureapitoisuutta ja heikensi rehuvalkuaisen hyväksikäyttöä samanaikaisesti niitettyyn heinäkasvirehuun verrattuna $(\mathrm{P}<0,001)$. Ero heinäkasvisäilörehuun verrattuna kuitenkin pienentyi, kun apilaa ruokittiin seoksena samanaikaisesti korjatun heinäkasvirehun kanssa $(\mathrm{P}<0,10)$.

\section{Johtopäätökset}

Lehmät söivät säilönnälliseltä laadultaan hyvää esikuivattua apilarehua enemmän kuin samaan aikaan korjattua vastaavaa heinäkasvisäilörehua. Lehmät söivät apilarehua myös enemmän kuin aikaisemmin korjattua ja sulavuudeltaan parempaa, mutta säilönnälliseltä laadultaan heikompaa heinäkasvisäilörehua. Koeruokintojen välillä ei ollut kuitenkaan tilastollisesti merkitseviä eroja energiakorjatussa maitotuotoksessa. Syötettäessä samaan aikaan korjattua apila- ja heinäkasvisäilörehua seoksena (1:1), säilörehun syönti ja energiakorjattu maitotuotos ylsivät lähes samalle tasolle kuin annettaessa puhdasta apilasäilörehua. Tällöin rehuvalkuaisen hyväksikäyttö maidontuotannossa oli parempi kuin puhdasta apilasäilörehua annettaessa.

Puna-apilan käyttäminen säilörehun raaka-aineena lisää säilörehun kuiva-aineen syöntiä ja maitotuotosta sekä vaikuttaa edullisesti maitorasvan koostumukseen. Puna-apilan syöntiin vaikuttavista tekijöistä samoin kuin korjuun ja säilönnän vaikutuksesta puna-apilasäilörehun rasvahappopitoisuuteen tarvitaan lisätutkimuksia.

\section{Kirjallisuus}

Dewhurst, R.J., Fisher, W.J., Tweed, J.K.S. \& Wilkins, R.J. 2003. Comparison of grass and legume silages for milk production. 1. Production responses with different levels of concentrate. Journal of Dairy Science 86: 2598-2611.

Huhtanen, P., Rinne, M. \& Nousiainen, J. 2007. Evaluation of the factors affecting silage intake of dairy cows: a revision of the relative silage dry-matter intake index. Animal 1: 758-770.

Huida, L., Väätäinen, H. \& Lampila, M. 1986. Comparison of dry matter contents in grass silages as determined by oven drying and gas chromatographic water analyses. Annales Agriculturae Fenniae 25: 215-230.

Sjaunja, L.O., Baevre, L., Junkkarinen, L., Pedersen, J. \& Setälä, J. 1991. A Nordic proposal for an energy corrected milk (ECM) formula. In: Gaillon, P. \& Chabert, Y. (eds.). Performance recording of animals: State of the art 1990. EAAP Publication no. 50, PUDOC, Wageningen, the Netherlands. p. 156-157.

Tuori, M., Griinari, T. \& Luukkainen, L. 2004. Puna-apila, vuohenherne- ja nurminatasäilörehujen vaikutus maidon linoleenihappopitoisuuteen lypsylehmän ruokinnassa. Julkaisussa: Maataloustieteen Päivät 2004 [verkkojulkaisu]. Suomen Maataloustieteellisen Seuran julkaisuja no 19. Toim. Anneli Hopponen ja Marketta Rinne. Viitattu [30.7.2007]. Julkaistu 5.1.2004. Saatavilla Internetissä: http://www.agronet.fi/maataloustieteellinenseura/Puna-apila, vuohenherne- ja nurminatasäilörehujen vaikutus maidon linoleenihappopitoisuuteen lypsylehmän ruokinnassa. ISBN 951-9041-47-8.

Vanhatalo, A., Gäddnäs, T., Heikkilä, T. 2006a. Microbial protein synthesis, digestion and lactation responses of cows to grass or grass-red clover silage diet supplemented with barley or oats. Agricultural and food science 15, 3. 252-267.

Vanhatalo, A. \& Jaakkola, S. 2006b. Onko puna-apilassa potentiaalia? Julkaisussa: Maataloustieteen Päivät 2006[verkkojulkaisu]. Suomen Maataloustieteellisen Seuran julkaisuja no 21. Toim. Anneli Hopponen. Viitattu [31.7.2007]. Julkaistu 9.1.2006. Saatavilla Internetissä: http://www.smts.fi// Onko puna-apilassa potentiaalia? ISBN 951-9041-49-4.

Vanhatalo, A., Kuoppala, K, Ahvenjärvi, S., \& Rinne, M. 2006c. Puna-apilasäilörehun vaikutus lypsylehmien ravintoaineiden saantiin. Julkaisussa: Maataloustieteen Päivät 2006 [verkkojulkaisu]. Suomen Maataloustieteellisen Seuran julkaisuja no 21. Toim. Anneli Hopponen.Viitattu [31.7.2007]. Julkaistu 9.1.2006. Saatavilla Internetissä: http://www.smts.fi/Puna-apilasäilörehun vaikutus lypsylehmien ravintoaineiden saantiin. ISBN 9519041-49-4. 
Vanhatalo, A., Kuoppala, K., Toivonen, V. \& Shingfield, K. 2007. Effects of forage species and stage of maturity on bovine milk fatty acid composition. European Journal of Lipid Science and Technology 109, 856867. 